\title{
SOME SOCIAL ASPECTS OF THE MEDICAL CARE OF DEAF MUTES
}

\author{
BY \\ E. MAURICE BACKETT AND A. ELIZABETH BROWN \\ From the Department of Social and Preventive Medicine, Queen's University of Belfast
}

In the medical care of the deaf mute, both diagnosis and treatment have benefited greatly from the advances in medical science of the last 20 years. But the advance has been mainly technical, and the study of the social handicaps of those deaf at birth or soon after, now widely admitted to be related to problems of medical care, inevitably lags behind the more exact researches.

The recent literature contains few results of surveys of the social needs of deaf mutes, though several writers stress their importance and make suggestions for meeting them. Thus, Johnson (1948) emphasized the need to help the parents of the deaf child and particularly the importance of parental understanding and education in the later adjustment of the growing deaf child to his disability. The Scottish Education Department (1950), in dealing with the problem of deaf children, also emphasized the importance of treating the family as a single unit, and suggested a permanent centre for the guidance of the families of deaf children in assisting the later adjustment of the affected child. Bakwin (1950), reviewing some of the social and psychological problems of deaf children in the United States, concluded that the handicap produces no characteristic personality distortion, and emphasizes the importance of parental attitude in adjustment; she referred to the dangers as well as the advantages of institutional treatment and suggested that being sent to an institution may make the deaf child feel rejected. Pintner and Brunschwig (1946) drew attention to the difficulties of adjustment of the deaf child, particularly where there are no other deaf relatives. Simon (1948) mentioned the ill effects on the deaf mute of his exclusion from normal responsibilities. Martens (1936) surveyed the work history of over 10,000 deaf persons who had received occupational training in school; his results showed that success in employment was not related to the amount of vocational training received.

\section{Methods}

Stevenson and Cheeseman (1956) have recently studied the genetic aspects of deaf mutism in Northern Ireland families. Their methods of ascertainment were such that it seems unlikely that many persons who were born deaf or who had been deaf from early childhood are absent from their records. This complete population presented a unique opportunity for a reappraisal of the needs of the deaf mute, an opportunity limited only by the resources of the department and by the relative inaccessibility of some of the patients. It was decided to limit the present inquiry initially to the age group where the most obvious of the major adjustments of life occur; that is, to deaf mutes between the ages of 16 and 30 years, when most of them would be leaving school, getting a job, and marrying. A limited assessment of the outstanding social problems related to their deafness was the object of this study.

Available resources permitted one visit to each patient's home by one of three social workers. Facts about the deaf mute's life were collected from the patient, and, where possible, from sibs and parents at a family interview. In addition, information was available from deaf missions, clubs, and hospital records, as described by Stevenson and Cheeseman (1956). Where an immediate need for medical or social care was encountered, action was taken within the limits set by the resources of the department. No controls were sought in this study, which was concerned with the deaf mute himself and not with the points in which he differed from the general population.

At the beginning of 1955 , there were 129 deaf mutes in Northern Ireland, 43 per 100,000 individuals, between the ages of 16 and 30 years. When a 
visit was attempted, seven had left the country, two did not wish to co-operate in the study, one had died, and no history was available for one who was a patient in a mental hospital. The remarks which follow refer to the remaining 118 patients who were visited. All these had been completely deaf at birth or had become deaf before speech had been acquired. 54 were under 21 years of age and unmarried, and of the remaining 64 , nineteen were married, six to deaf persons in the population under review, eleven to other deaf persons, and two to hearing persons (in both cases the deaf partner was the husband).

\section{RESULTS}

\section{Problems of the Deaf Mute}

The problems which could be investigated by the methods at our disposal were related to communication, social relationships, employment, and relations with authority. Just over half the population, 67 individuals, had encountered one or more problems, and 22 had had three or more, but not all these problems were serious. The incidence of similar problems among the general population is not known. Table I summarizes their occurence among the 118 deaf mutes in this study.

TABLE I

FREQUENCY OF PROBLEMS

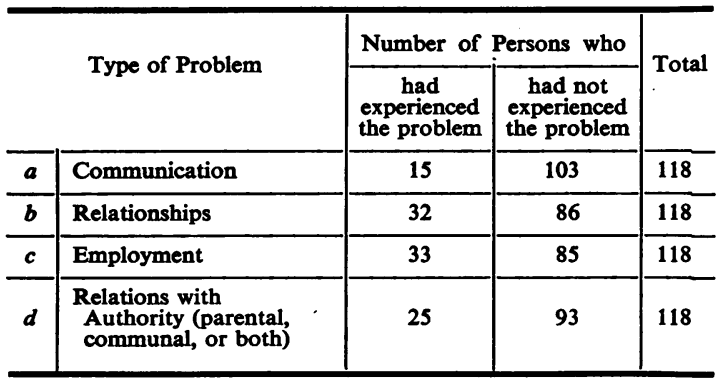

(a) Communication.- The deaf mutes in this study, who were of normal intelligence and had received an adequate education, appeared to have little difficulty in communicating with one another. While communication is obviously a "two-way" process, the main problems encountered lay in expression rather than in understanding. They were problems of how to communicate with the outside world and did not often derive from inability to lip-read or to understand the expressive movements of hearing people. For a few some crude sort of speech had been learned but for a very small proportion, whose education was deficient or whose lives had been confined wholly within the family circle, there was almost no method of communication beyond a few personal signs and sounds.

The methods of communication used are summarized in Table II. About one in eight of this population could not communicate with hearing people who did not themselves know some special technique; these included five who, though apparently able to read and write, did not use these skills in communicating with others.

TABLE II

METHODS OF COMMUNICATION

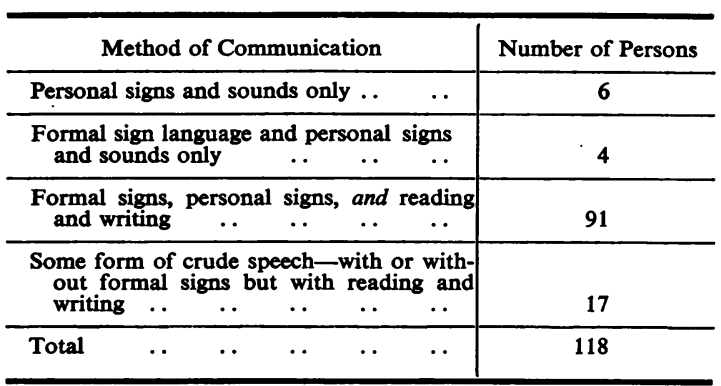

Communication is of course the central problem in the life of the deaf mute, and for those who cannot communicate adequately with hearing people any sort of normal life is exceptionally difficult.

(b) Social Relationships.-This aspect of the life of the deaf mute is particularly likely to be affected. However, objective measurement is very difficult, and no attempt was made to do more than note those who, for personal, geographic, or other reasons, suffered a marked restriction of normal relationships. Where there was no evidence of more than two friends or companions outside the family group, the social relations of the deaf mute were regarded as "restricted".

Among the 118 subjects, 32 were restricted in this way. Often the accompanying information suggested an unusual degree of shyness and withdrawal from contacts outside the family. For eight this withdrawal was even more marked, and social relations were limited to one or two other deaf persons onlythe family being excluded. In four cases withdrawal was extreme and the mutes were almost completely isolated.

The worst problems were encountered in geographically isolated families, where it appeared that over-protection and lack of understanding on the part of parents, coupled with the inability to communicate, had made the deaf mute an outcast, a 
figure of fun, or a recluse. For example, two deaf mute girls had hardly been allowed out of the house for 20 years, and in consequence were without any education at all, could communicate only with their mother by personal signs, and had no friends, and no skills other than housework. The mother is elderly, and after her death the girls will be quite unable to communicate with hearing people.

For the majority of young deaf mutes the company of others equally deaf is the only sort of social life worth having and it is apparently full and satisfactory. However, it depends entirely upon access to the deaf community and the isolation of the countryside may impose a barrier.

(c) Employment.-84 deaf mutes were in employment or apprenticed at the time of this study, six were married women looking after their own homes, and two had occasional or part-time labouring jobs. Two were still at school, and of the remaining 24, six were in hospital or suffering from chronic illness at home, four were mentally retarded to a degree that may have interfered with normal employment, two were in a welfare institution for their care and protection, and four were "not allowed" to work by their parents. Only eight were unemployed in the strict sense of being unable to find employment. Thus, of the 118 subjects, sixteen were for some reason unfit, eight were unemployed, and the rest were employed or training for employment. When the work histories were examined, the difficulty of getting and keeping a job became clearer. Just under one-third had encountered great difficulty, and some of those in employment were probably under-employed, i.e. were employed below their capacity. The inevitable trend toward more menial tasks was observed between normal parents and their deaf offspring and was more obvious among those inadequately educated or without vocational training. Many employers try or can be persuaded to employ a few deaf mutes either as a charitable gesture or because they are said to be "very good workers". Other employers who require the performance of tasks in which the deaf fare better than the hearing (certain very noisy processes for example) appear to have made no effort to obtain deaf employees. The main credit for the surprisingly high incidence of employment is attributable to the energy of the deaf mutes themselves and to the officers of the Deaf Missions.

In a community in which there is widespread unemployment, the Disabled Persons Register should give special protection to the handicapped. All but nine of the deaf mutes were on this register, but it appeared to have little meaning for them, and to protect them hardly at all. (d) Relations with Authority.-The few reports of overt, aggressive, and antisocial behaviour-ranging from histories of "rages" and "tempers" to a court sentence for assault-did little to disturb the impression of a law-abiding, hard-working group. Twenty of the 118 had a history of mildly aggressive or antisocial behaviour, being "difficult and especially bad-tempered" at home or responsible for minor delinquencies at Mission or Club. There were five examples of more serious behaviour defects. Many reports from parents suggested strongly individualistic behaviour among the deaf mutes, and there is no doubt that some were seriously provoked by the attitude of their families to their disability. This was most marked in the few families in which the deaf mute was ignored or regarded as a figure of fun.

\section{Circumstances Related to Problems of the DeAF Mute}

A number of personal and family influences which might be associated with the problems of deaf mutes were investigated. One of these was the size of the community in which the deaf mute was living.

Table III, which is based upon all problems of deafo mutes, suggests that the frequency of problems is influenced by the size of the community. The frequency is lower in cities than in small towns or rural areas $\left(\chi^{2}=9 \cdot 49 ; D . F .=1 ; P<0.01\right)$ and lower in small towns and cities than in rural areas $\left(\chi^{2}=\right.$ $14 \cdot 26 ; D . F .=1 ; P<0.001)$.

TABLE III

FREQUENCY OF PROBLEMS RELATED TO TYPE OF COMMUNITY

\begin{tabular}{|c|c|c|c|c|c|c|}
\hline \multirow{3}{*}{$\begin{array}{c}\text { Type of } \\
\text { Community }\end{array}$} & \multicolumn{6}{|c|}{ Number of Deaf Mutes with } \\
\hline & \multicolumn{2}{|c|}{ Problems } & \multicolumn{2}{|c|}{ No Problems } & \multicolumn{2}{|c|}{ Total } \\
\hline & No. & Per cent. & No. & Per cent. & No. & Per cent. \\
\hline City $\quad \ldots$ & 27 & 43 & 36 & 57 & 63 & 100 \\
\hline Small town & 17 & 57 & 13 & 43 & 30 & 100 \\
\hline Rural area & 23 & .92 & 2 & 8 & 25 & 100 \\
\hline Total .. & 67 & & 51 & & 118 & \\
\hline
\end{tabular}

In Table IV (opposite) attention is restricted to the 41 deaf mutes with serious problems; here again the frequency is influenced by size of community.

Several other influences which might be related to the frequency of problems of deaf mutes were also examined. No significant association was found with age, sex, the presence of another deaf person within 
TABLE IV

FREQUENCY OF SERIOUS PROBLEMS RELATED TO TYPE OF COMMUNITY

\begin{tabular}{|c|c|c|c|c|c|c|}
\hline \multirow{3}{*}{$\begin{array}{l}\text { Type of } \\
\text { Community }\end{array}$} & \multicolumn{6}{|c|}{ Number of Deaf Mutes with } \\
\hline & \multicolumn{2}{|c|}{$\begin{array}{c}\text { Serious } \\
\text { problems }\end{array}$} & \multicolumn{2}{|c|}{$\begin{array}{l}\text { No serious } \\
\text { problems }\end{array}$} & \multicolumn{2}{|c|}{ Total } \\
\hline & No. & Per cent. & No. & Per cent. & No. & Per cent. \\
\hline City & 16 & 25 & 47 & 75 & 63 & 100 \\
\hline Small town & 11 & 37 & 19 & 63 & 30 & 100 \\
\hline Rural area & 14 & 56 & 11 & 44 & 25 & 100 \\
\hline Total ... & 41 & & 77 & & 118 & \\
\hline
\end{tabular}

the family, family size, or death or separation of parents during childhood. The association was suggestive, but not significant by the conventional tests, in respect of family health and income. A significant association was noted only in relation to religion, education, and vocational training (Table V).

In spite of the small numbers involved, it was thought to be worth while to examine the interaction of the main factors (Table VI). The results may be summarized as follows:

(1) The association of problems with 'urban' or 'rural' life was present when the factors of religion and vocational training were held constant.

(2) The association of problems with vocational training was present when the factors of 'rural' or 'urban' life and religion were held constant.

(3) The association of problems with religion was only slightly suggestive when the factors of 'rural' or 'urban' life and vocational training were held constant.

These results suggest that the most significant influences affecting the frequency of problems of deaf mutes are social isolation, which is largely determined by place of residence, and lack of educational and vocational training.

TABLE V

INFLUENCES RELATED TO THE FREQUENCY OF PROBLEMS

\begin{tabular}{|c|c|c|c|c|c|c|c|c|c|c|c|c|}
\hline \multirow{2}{*}{\multicolumn{4}{|c|}{ Social Circumstance }} & \multicolumn{6}{|c|}{ Number of Deaf Mutes with } & \multirow{3}{*}{$x^{2}$} & \multirow{3}{*}{$\begin{array}{l}\text { Degrees of } \\
\text { Freedom }\end{array}$} & \multirow{3}{*}{$P$} \\
\hline & & & & \multicolumn{2}{|c|}{ Problems } & \multicolumn{2}{|c|}{ No Problems } & \multicolumn{2}{|c|}{ Total } & & & \\
\hline & & & & No. & Per cent. & No. & Per cent. & No. & Per cent. & & & \\
\hline Religion & .. & $\begin{array}{l}\text { Catholic } \\
\text { Protestant }\end{array}$ & .. & $\begin{array}{l}30 \\
37\end{array}$ & $\begin{array}{l}70 \\
49\end{array}$ & $\begin{array}{l}13 \\
38\end{array}$ & $\begin{array}{l}30 \\
51\end{array}$ & $\begin{array}{l}43 \\
75\end{array}$ & $\begin{array}{l}100 \\
100\end{array}$ & $3 \cdot 85$ & 1 & $0.05>P>0.01$ \\
\hline Education & .. & $\begin{array}{l}\text { Inadequate } \\
\text { Adequate }\end{array}$ & 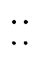 & $\begin{array}{l}14 \\
53\end{array}$ & $\begin{array}{l}88 \\
52\end{array}$ & $\begin{array}{r}2 \\
49\end{array}$ & $\begin{array}{l}12 \\
48\end{array}$ & $\begin{array}{r}16 \\
102\end{array}$ & $\begin{array}{l}100 \\
100\end{array}$ & $5 \cdot 74$ & 1 & $0.02>P>0.01$ \\
\hline $\begin{array}{l}\text { Vocational } \\
\text { Training }\end{array}$ & .. & $\begin{array}{l}\text { None } \ldots \\
\text { Some } \ldots\end{array}$ & $\ddot{.}$ & $\begin{array}{l}44 \\
23\end{array}$ & $\begin{array}{l}68 \\
43\end{array}$ & $\begin{array}{l}21 \\
30\end{array}$ & $\begin{array}{l}32 \\
57\end{array}$ & $\begin{array}{l}65 \\
53\end{array}$ & $\begin{array}{l}100 \\
100\end{array}$ & $6 \cdot 06$ & 1 & $0.02>P>0.01$ \\
\hline
\end{tabular}

TABLE VI

INTERACTION OF INFLUENCES RELATED TO FREQUENCY OF PROBLEMS

\begin{tabular}{|c|c|c|c|c|c|c|c|}
\hline \multicolumn{3}{|c|}{ Social Factors } & \multicolumn{2}{|c|}{$\begin{array}{l}\text { Observed as a } \\
\text { Percentage of } \\
\text { Expected** } \\
\text { Deaf Mutes }\end{array}$} & \multirow{2}{*}{$\begin{array}{c}x^{2} \\
\text { (Based on } \\
\text { absolute } \\
\text { numbers) }\end{array}$} & \multirow{2}{*}{$\begin{array}{l}\text { Degrees of } \\
\text { Freedom }\end{array}$} & \multirow[t]{2}{*}{$P$} \\
\hline Held Constant & \multicolumn{2}{|c|}{ Examined } & $\begin{array}{c}\text { With } \\
\text { Problems }\end{array}$ & $\begin{array}{l}\text { With no } \\
\text { Problems }\end{array}$ & & & \\
\hline $\begin{array}{l}\text { Religion and } \\
\text { Vocational Training }\end{array}$ & Residence in & $\begin{array}{l}\text { City } \\
\text { Small Town or } \\
\text { Rural Area }\end{array}$ & $\begin{array}{r}76 \\
127\end{array}$ & $\begin{array}{r}131 \\
64\end{array}$ & $9 \cdot 92$ & 1 & $0.01>P>0.001$ \\
\hline \multirow{2}{*}{$\begin{array}{l}\text { Religion and } \\
\text { Life in City or in } \\
\text { Small Town and } \\
\text { Rural Area.. }\end{array}$} & \multirow{2}{*}{$\begin{array}{l}\text { Vocational } \\
\text { Training .. }\end{array}$} & Present & 80 & 121 & \multirow[b]{2}{*}{$4 \cdot 38$} & \multirow[b]{2}{*}{1} & \multirow[b]{2}{*}{$0.05>P>0.02$} \\
\hline & & Absent & 114 & 79 & & & \\
\hline \multirow{2}{*}{$\begin{array}{l}\text { Vocational Training and } \\
\text { Life in City or in } \\
\text { Small Town and } \\
\text { Rural Area.. .. }\end{array}$} & \multirow[t]{2}{*}{ Religion } & Catholic & 116 & 74 & \multirow[b]{2}{*}{$2 \cdot 75$} & \multirow[b]{2}{*}{1} & \multirow[b]{2}{*}{$0.10>P>0.05$} \\
\hline & & Protestant .. & 89 & 112 & & & \\
\hline
\end{tabular}

* Calculated on the hypothesis that there was no difference in the proportion of persons with special problems in each category of the factor examined, at each of the four categories derived from the double classification of the two factors held constant. 
There are two special schools to which protestant deaf children in the Province of Ulster can go; the catholics attend one of two schools in Eire. The majority of those in the study (102) had spent at least five years at one of these schools, but of the remaining sixteen of the 118, three had had no education at all, one had not been sent to a special school, and twelve had attended a special school for less than five years. The schooling of this group of sixteen was inadequate by any standards, and this represents a breakdown of services which is as important to the deaf mute as a deficiency in physiotherapy would be to the polio cripple. By the more stringent, yet generally accepted criterion of ten years at a special school, more than 50 per cent. had had an inadequate education. Formal apprenticeship or some type of trade training was enjoyed by only 52 of the 118 . Yet such training is an essential part of the equipment of the deaf mute, compensating to some small extent for his handicap in his search for satisfactory employment. Unfortunately, those with inadequate early education were also those who had suffered through lack of apprenticeship and were thus doubly handicapped at the outset. No doubt a parallel study of present facilities for school-age deaf mutes would show an improvement upon this highly unsatisfactory picture, but about half of those who are now between 16 and 30 years of age in Northern Ireland have already suffered an irreparable loss of skill through inadequate schooling and absence of training. The cumulative effect of their deaf-mutism, poor education, and lack of vocational training is an insuperable barrier between them and a "normal" life, which forces them to a variety of "dead-end" jobs, often below those which their intelligence or aptitude appear to deserve.

\section{Adjustment}

It was impossible in one interview, even with information from other sources, to do more than record the crudest indices of the adjustment of the deaf mute. However, it was soon obvious that many of these young adults had established a relatively normal attitude to life, and an attempt was made to assess the numbers and status of those who had not.

The criteria considered were home-making, employment, maintenance of friendships, relations with parents, teachers, and supervisors, and leisure activities. The results suggested that at least half of the deaf mutes were leading fairly normal successful lives. Of the remaining 50 per cent., half were not able to get or to keep jobs, could not lead a normal social life, or were in some other way apparently not "making a go of things".

The factors which determine whether a deaf mute can settle down to live a normal existence are not likely to be less complex than those governing the adjustment of the ordinary individual. However, because of his special disability, a few problems asscciated with his deafness are likely to be of particular importance to him. It is possible, too, that he will have special assets which help him to face his problems; according to local folklore, deaf mutes are particularly hardworking, honest, conscientious, and loyal. In this inquiry, there was no serious evidence to the contrary, though a study of such intangible assets (all factors which would make for the "healthiness" and good adjustment of the deaf mute) is much more difficult than a study of the problems and disadvantages associated with deafness. It might be thought that the deaf mutes who had had many problems would show the poorest adjustment, but this was apparently only partly true, for at least onethird of those who had encountered problems in the past were "making a go" of their lives when interviewed, and eighteen of the 41 whose problems were among the most serious showed good adjustment.

\section{SUMmary}

Of 129 deaf mutes between the ages of 16 and 30 years in Northern Ireland, 118 were visited in 1955. Some of their major social problems-communication, social relationships, employment, and relations with authority-were found to be associated with inadequate education, insufficient vocational training, and residence in rural areas or small towns. The problems were possibly, but not definitely, associated with religion, family income, and health. An attempt was made to assess the success of deaf mutes in overcoming their handicaps.

We are grateful to Miss $\mathbf{M}$. Douglas and Miss $J$. Kinnaird for their help in collecting the material of this study, to Mr. Townsend of the Church of Ireland Mission for the Adult Deaf, to Dr. Allen of the Kingham Mission for the Deaf, and to Mr. Creaney of St. Joseph's Hall for the Deaf and Dumb. We are also grateful to our collleagues in the Department of Social and Preventive Medicine of the Queen's University of Belfast for their help, to Mr. J. D. Merrett and Mr. S. Crockett for their computing assistance, to Miss Stewart who typed the paper, and particularly to Dr. E. A. Cheeseman for his method of small number standardization.

\section{REFERENCES}

Backwin, R. M. (1950). J. Pediat., 36, 668.

Johnson, W. E. (1948). Med. J. Aust., $2,13$.

Martens, H. E. (1936). "The Deaf. and the Hard-of-Hearing in the Occupational World". United States Department of the Interior, Bulletin No. 13. Washington.

Pintner, R., and Brunschwig, L. (1936). J. genet. Psychol., 49, 377.

Scottish Education Department (1950). "Pupils who are Defective in Hearing. A Report of the Advisory Council on Education in ScotHearing. A Report of the Adviso

Simon, A. B. (1948). "Let the Deaf Grow Up". Volta Rev., 50, 166.

Stevenson, A. C., and Cheeseman, E. A. (1956). Ann. hum. Genet., $20,177$. 